\title{
Elaidic acid and vaccenic acid in the plasma of pregnant women and umbilical blood plasma
}

\author{
Występowanie kwasu elaidynowego i wakcenowego w osoczu kobiet ciężarnych \\ oraz we krwi pępowinowej
}

\author{
'Zakład Biochemii i Żywienia Człowieka Pomorskiego Uniwersytetu Medycznego w Szczecinie \\ ul. Broniewskiego 24, 71-460 Szczecin \\ Kierownik: prof. dr hab. n. med. Ewa Stachowska \\ ${ }^{2}$ Katedra Biochemii i Chemii Medycznej Pomorskiego Uniwersytetu Medycznego w Szczecinie \\ al. Powstańców Wlkp. 72, 70-111 Szczecin \\ Kierownik: prof. dr hab. n. med. Dariusz Chlubek
}

Dominika Jamioł-Milc1, Ewa Stachowska', Tomasz Janus', Anna Barcz¹, Dariusz Chlubek²

\section{SUMMARY}

Introduction: The studies suggest that trans fatty acids are the most harmful type of fatty acids, and their ingestion leads to an increase in oxidative stress, changes in the plasma levels of LDL cholesterol, and a reduction in $n-6$ and n- 3 fatty acids utilization.

The objective of this study was to determine the concentration profiles of elaidic and vaccenic acids in maternal blood plasma in the perinatal period, and in the plasma of blood collected from the umbilical vein. The article deals with the issue of the correlation between the levels of trans-unsaturated fatty acids in maternal and neonatal blood, which could suggest the transplacental transport of these acids. The potential correlations between the levels of trans-unsaturated fatty acids in maternal and umbilical blood and birth weight and body length in neonates was also verified.

Material and methods: The study group comprised 53 pregnant patients of the Clinic of Obstetrics and Perinatology of the Pomeranian Medical University in Szczecin, aged 18-39 years, together with their newborn babies. Elaidic and vaccenic acid levels were determined in maternal and umbilical plasma. Fatty acid methyl esters were injected onto the capillary column of the Agilent $6890 \mathrm{M}$ gas chromatography system integrated with an autosampler. The content of individual fatty acids was determined from the reference curves and expressed in $\mathrm{mg} / \mathrm{mL}$.

Results: The lowest levels of both acids were observed in umbilical blood plasma. The level of elaidic acid was $0.0019 \mathrm{mg} / \mathrm{mL} \pm 0.0013 \mathrm{mg} / \mathrm{mL}$, while the level of vaccenic acid was $0.0007 \mathrm{mg} / \mathrm{mL} \pm 0.0011 \mathrm{mg} / \mathrm{mL}$. A statistically significant negative correlation was observed between maternal vaccenic acid levels and umbilical vaccenic acid levels.

Conclusions: The presence of trans-unsaturated fatty acids (elaidic acid and vaccenic acid) in umbilical plasma is evidence of the transplacental transport of these acids. The significantly higher levels of elaidic acid compared to vaccenic acid in umbilical plasma suggests that vaccenic acid is more extensively metabolized in placenta. The levels of trans-unsaturated fatty acids had no effect on birth weight and body length in neonates.

Key words: trans fatty acids , vaccenic acid, elaidic acid, pregnancy, cord blood.

\section{STRESZCZENIE}

Wstęp: W wielu badaniach wykazano, że nienasycone kwasy tłuszczowe typu trans są najbardziej szkodliwym rodzajem kwasów tłuszczowych, a ich spożywanie może prowadzić do nasilenia stresu oksydacyjnego, niekorzystnych zmian stężenia frakcji cholesterolu LDL oraz zaburzać metabolizm kwasów tłuszczowych z rodziny omega- 6 i omega- 3 .

Celem pracy było określenie tego, jak kształtują się stężenia kwasu elaidynowego i wakcenowego w osoczu krwi kobiet w okresie okołoporodowym, osoczu krwi pobranej z żyły pępowinowej oraz ustalenie, czy istnieją zależności pomiędzy stężeniami nienasyconych kwasów tłuszczowych typu trans we krwi matek i ich dzieci, co mogłoby wskazywać na istnienie przezłożyskowego transportu tych kwasów. Określono także korelacje pomiędzy stężeniami nienasyconych kwasów tłuszczowych typu trans we krwi matek i krwi żyły pępowinowej a masą i długością ciała noworodków.

Materiał i metody: Badaniami objęto 53 kobiety w wieku 18-39 lat, pacjentki bloku operacyjno-porodowego Kliniki
Położnictwa i Perinatologii Pomorskiego Uniwersytetu Medycznego w Szczecinie oraz ich noworodki. W osoczu krwi ciężarnych i krwi pępowinowej oznaczono zawartość kwasu elaidynowego i wakcenowego. Estry metylowe kwasów tłuszczowych nastrzykiwano na kolumnę kapilarną chromatografu gazowego 6890M Agilent wyposażonego w autosampler. Izomery geometryczne i pozycyjne kwasów tłuszczowych były identyfikowane na podstawie porównania czasów retencji z wzorcami kwasów tłuszczowych firmy Sigma-Aldrich. Zawartość poszczególnych kwasów tłuszczowych odczytywano na podstawie krzywych wzorcowych i wyrażono $\mathrm{w} \mathrm{mg} / \mathrm{mL}$

Wyniki: Najniższe stężenie obydwu kwasów tłuszczowych zaobserwowano w osoczu krwi pępowinowej. Stężenie kwasu elaidynowego kształtowało się na poziomie $0,0019 \mathrm{mg} / \mathrm{mL}$ $\pm 0,0013 \mathrm{mg} / \mathrm{mL}$, natomiast kwasu wakcenowego: $0,0007 \mathrm{mg} / \mathrm{mL}$ $\pm 0,0011 \mathrm{mg} / \mathrm{mL}$. Zaobserwowano istotną statystycznie ujemną korelacje pomiędzy stężeniem kwasu wakcenowego w osoczu matki i osoczu krwi pępowinowej. 
Wnioski: Obecność kwasu wakcenowego i kwasu elaidynowego w osoczu krwi z żyły pępowinowej jest dowodem na istnienie ich transportu przezłożyskowego. Istotnie większe stężenie kwasu elaidynowego w osoczu krwi pępowinowej w porównaniu ze stężeniem kwasu wakcenowego może świadczyć o większym natężeniu metabolizmu kwasu wakcenowego w łożysku.
Stężenia nienasyconych kwasów tłuszczowych typu trans nie miały wpływu na masę urodzeniową i długość ciała noworodków.

Słowa kluczowe: nienasycone kwasy tłuszczowe typu trans, kwas wakcenowy, kwas elaidynowy, ciąża, krew pępowinowa.

\section{INTRODUCTION}

Trans-unsaturated fatty acids (TFAs) became an object of particular interest due to their relationship with cardiovascular diseases $[1,2,3,4]$. Numerous studies showed that TFAs are the most harmful type of fatty acids, and that their ingestion leads to an increase in the plasma levels of LDL cholesterol while reducing the levels of HDL cholesterol $[3,5,6]$. Increased oxidative stress, also associated with the ingestion of TFAs [7], may initiate or accelerate the course of many inflammatory diseases $[1,2,3,4,6,8,9,10,11,12,13,14,15,16,17]$. By inhibiting the activity of $\Delta^{6}$-desaturase, TFAs reduce the degree to which n- 6 and n-3 fatty acids are utilized in the synthesis of anticoagulant prostaglandins $[18,19,20,21,22,23,24]$.

Trans-fatty acids cannot be synthesized de novo in the human body; thus, their presence in tissues and systemic fluids is the result of the ingestion of TFA-containing foods $[7,25]$. Trans-fatty acids are produced in the industrial processing of vegetable oils $[26,27,28]$, or in the process of biohydrogenation mediated by bacterial flora in the stomachs of ruminants; their structure includes at least one double bond with trans configuration [27, 29].

Products containing industrially hardened vegetable and fish oils are the main source of TFAs in the human diet, accounting for more than $60 \%$ of the total amount consumed [28, 30, 31]. The TFA content in milk/dairy and meat is 30\%, and $10 \%$ of the total fatty acid content, respectively [30]. At the same time, the content of TFAs in hardened vegetable oils is at the level of $10-40 \%$ [32].

Most common are the trans isomers of octadecanoic acid C18:1, accounting for $80-90 \%$ of all TFAs present in food. The predominant trans isomer found in the fat of ruminant animals is vaccenic acid (C18:1; trans-11), accounting for 40-80\% of all trans isomers of C18:1 [7,33]. Elaidic acid (C18:1; trans-9) has the highest share in the structure of fats produced by the industry $[32,33,34]$.

The purpose of the study was to determine the concentration profiles of elaidic and vaccenic acids in maternal blood plasma in the perinatal period, and in the plasma of blood collected from the umbilical vein. The article deals with the issue of the correlation between the levels of trans-unsaturated fatty acids in maternal and neonatal blood, which could be suggestive of the transplacental transport of these acids. The existence of potential correlations between the levels of trans-unsaturated fatty acids in maternal and umbilical blood and birth weight and body length in neonates was verified.

\section{MATERIAL AND METHODS}

\section{Study population}

The study protocol was approved by the Ethics Committee of the Pomeranian Medical University in Szczecin (PMU), and the study was performed in accordance with the ethical standards laid down in the 1964 Declaration of Helsinki and its later amendments. All subjects gave their informed consent prior to their inclusion in the study.

The study population comprised 53 patients of the Surgery and Delivery Room of the Clinic of Obstetrics and Perinatology of the PMU and their newborns, delivered between June and August in the years 2007 and 2008. The inclusion criteria included the exclusion of any pathology of the pregnancy, and lack of concomitant chronic diseases before pregnancy. The mean age of patients was 29.11 years. 32 women were uniparous, while 21 were multipars. The morphological and functional maturity of neonates was adequate to their gestational age.

\section{Analysis of fatty acids}

Blood samples were collected into vacuum tubes with EDTA anticoagulant in fasting conditions from the basilic veins of mothers at the first stage of delivery; umbilical vein blood was collected immediately after clamping of the umbilical cord. The samples were centrifuged for 10 minutes at $4^{\circ} \mathrm{C}$ and $1800 \times \mathrm{g}$. The plasma was frozen and stored at $-80^{\circ} \mathrm{C}$ until used for analysis.

Lipids were extracted from the study material using Folch reagent, and then hydrolyzed to obtain fatty acids that were later transformed into methyl esters. Fatty acid methyl esters were injected onto a capillary column (CP-SIL88 $50 \mathrm{M} \times 0.25 \mathrm{~mm}$ ID, film thickness $0.2 \mu \mathrm{m}$, Varian) of an Agilent $6890 \mathrm{M}$ gas chromatography system integrated with an autosampler. The temperature of the detector was $270^{\circ} \mathrm{C}$. Geometrical and positional isomers of fatty acids were identified by comparing their retention times with those of the fatty acid standards from Sigma-Aldrich. The content of individual fatty acids was determined from the reference curves, and expressed in $\mathrm{mg} / \mathrm{mL}$.

\section{Statistical analyses}

The obtained data were verified by classical descriptive and mathematical statistics using Statistica software. The distribution of analyzed variables was close to normal, which facilitated the correlation analysis, consisting in the calculation of 
Pearson's coefficient of correlation $r$, and tests for the significance of this coefficient. Next, the obtained value was compared to the critical value listed in Student's t-test value tables for $n-2$ degrees of freedom and the assumed significance level $\alpha$. Significant coefficients of correlation are listed in tables $(\alpha=0.05)$. Analysis of variance (ANOVA) was used to determine the difference in the means of the tested variables, with the significance level $\alpha=0.05$.

\section{RESULTS}

\section{Maternal characteristics, pregnancy course and neonatal birth parameters}

The data concerning maternal age, body mass index (BMI), pregnancy weight gain and gestation weeks of delivery are presented in Table 1

The data concerning the birth weight and body length of the neonates are presented in Table 2 .

The coefficients of variability obtained for neonatal body length (including those determined with consideration to female and male sex) suggest a poor, statistically non-significant variability (Table 3).

Comparison of mean concentrations of elaidic acid and vaccenic acid in maternal plasma (MP) and umbilical blood plasma (UP). The lowest levels of both acids were observed in umbilical blood plasma. The elaidic acid levels were as follows: MP $0.0136 \mathrm{mg} / \mathrm{mL} \pm 0.0088 \mathrm{mg} / \mathrm{mL}$, UP $0.0019 \mathrm{mg} / \mathrm{mL} \pm 0.0013$ $\mathrm{mg} / \mathrm{mL}$, while the vaccenic acid levels were: $\mathrm{MP} 0.0102 \mathrm{mg} / \mathrm{mL}$ $\pm 0.0059 \mathrm{mg} / \mathrm{mL}$, OP $0.0007 \mathrm{mg} / \mathrm{mL} \pm 0.0011 \mathrm{mg} / \mathrm{mL}$ (Table 4); the differences were statistically significant (Table 5).
Table 6 presents the percentage share of maternal plasma samples and umbilical blood plasma samples in which elaidic acid or vaccenic acid were not detected.

\section{Correlations}

The statistically significant correlations between the elaidic acid and vaccenic acid levels and the levels of other fatty acids in maternal plasma are listed in Table 7. The analysis of correlations between the levels of fatty acids in umbilical plasma revealed a statistically significant positive correlation between the levels of elaidic acid and vaccenic acid. No correlations were observed between the TFA levels and the polyunsaturated fatty acids (PUFA) levels (Table 8).

A statistically significant, negative correlation was observed between maternal vaccenic acid levels and umbilical vaccenic acid levels (Table 8).

No correlations were observed between the elaidic acid levels and the levels of the remaining fatty acids. No correlations were found between the levels of elaidic acid and vaccenic acid in maternal and umbilical plasma and the birth weight and body length of the newborns.

\section{DISCUSSION}

Trans-fatty acids, absorbed in the intestine, may undergo such metabolic transformations as oxidation, chain elongation and generation of additional double bonds or accumulation in the adipose tissue. Trans-fatty acids may be incorporated into cellular structures (particularly into individual phospholipid fractions), leading to changes in cellular membrane

TABLE 1. Characteristics of pregnant women $(n=53)$ and pregnancy course data

\begin{tabular}{|c|c|c|c|c|c|c|c|}
\hline Parameters & Mean \pm SD & Median & Min. & Max. & $\begin{array}{l}\text { Lower } \\
\text { quartile }\end{array}$ & $\begin{array}{l}\text { Upper } \\
\text { quartile }\end{array}$ & $\begin{array}{c}\text { Coefficient of } \\
\text { variability }\end{array}$ \\
\hline Age (years) & $29.1 \pm 4.8$ & 29 & 18 & 39 & 26 & 39 & $16.4 \%$ \\
\hline Pre-pregnancy body weight (kg) & $62.9 \pm 12.1$ & 61 & 44 & 100 & 56 & 68 & $19.2 \%$ \\
\hline Pre-pregnancy BMI (kg/m²) & $22.6 \pm 3.8$ & 21.5 & 17.6 & 34.4 & 19.8 & 25 & $17.0 \%$ \\
\hline Gestation week upon delivery & $39.9 \pm 1.4$ & 40 & 36 & 42 & 39 & 41 & $3.5 \%$ \\
\hline Pregnancy weight gain (kg) & $16.7 \pm 5.1$ & 15.5 & 8.7 & 29 & 13 & 21 & $30.5 \%$ \\
\hline
\end{tabular}

TABLE 2. Birth parameters of neonates $(n=53)$

\begin{tabular}{|c|c|c|c|c|c|c|c|}
\hline Parameters & Mean \pm SD & Median & Min. & Max. & $\begin{array}{c}\text { Lower } \\
\text { quartile }\end{array}$ & $\begin{array}{c}\text { Upper } \\
\text { quartile }\end{array}$ & $\begin{array}{c}\text { Coefficient of } \\
\text { variability }\end{array}$ \\
\hline Birth weight (g) & $3512 \pm 498$ & 3570 & 2470 & 4350 & 3100 & 3900 & $14.2 \%$ \\
\hline Body length $(\mathrm{cm})$ & $55.9 \pm 3$ & 56 & 49 & 65 & 54 & 57 & $5.3 \%$ \\
\hline
\end{tabular}

TABLE 3. Birth parameters of neonates with consideration to female $(n=24)$ and male $(n=29)$ sex

\begin{tabular}{|c|c|c|c|c|c|c|c|}
\hline Parameters & Mean \pm SD & Median & Min. & Max. & $\begin{array}{l}\text { Lower } \\
\text { quartile }\end{array}$ & $\begin{array}{c}\text { Upper } \\
\text { quartile }\end{array}$ & $\begin{array}{c}\text { Coefficient of } \\
\text { variability }\end{array}$ \\
\hline Birth weigh of female neonates (g) & $3431 \pm 499$ & 3565 & 2470 & 4175 & 2980 & 3735 & $14.5 \%$ \\
\hline Body length of female neonates (cm) & $55 \pm 2.6$ & 56 & 50 & 59 & 54 & 57 & $4.7 \%$ \\
\hline Body length of male neonates $(\mathrm{cm})$ & $56 \pm 3.2$ & 56 & 49 & 65 & 54 & 59 & $5.6 \%$ \\
\hline
\end{tabular}


TABLE 4. Levels of the analyzed fatty acids in the study material $(n=53)$

\begin{tabular}{lcccc}
\multirow{2}{*}{ Parameters } & \multicolumn{2}{c}{ Maternal plasma } & \multicolumn{2}{c}{ Umbilical blood plasma } \\
\cline { 2 - 5 } & elaidic acid & vaccenic acid & elaidic acid & vaccenic acid \\
\hline Mean $\pm \mathrm{SD}(\mathrm{mg} / \mathrm{mL})$ & $0.0136 \pm 0.0088$ & $0.0102 \pm 0.0059$ & $0.0019 \pm 0.0013$ & $0.0007 \pm 0.0011$ \\
\hline Median $(\mathrm{mg} / \mathrm{mL})$ & 0.0113 & 0.0090 & 0.0019 & 0.0000 \\
\hline Minimum $(\mathrm{mg} / \mathrm{mL})$ & 0.0000 & 0.0000 & 0.0000 & 0.0000 \\
\hline Maximum $(\mathrm{mg} / \mathrm{mL})$ & 0.0496 & 0.0317 & 0.0045 & 0.0045 \\
\hline Lower quartile $(\mathrm{mg} / \mathrm{mL})$ & 0.0085 & 0.0066 & 0.0014 & 0.0000 \\
\hline Upper quartile $(\mathrm{mg} / \mathrm{mL})$ & 0.0152 & 0.0124 & 0.0026 & 0.0012 \\
\hline Coefficient of variability $(\%)$ & 64.3 & 58.2 & 67.9 & 175.1 \\
\hline
\end{tabular}

TABLE 5. ANOVA analysis for medium levels of elaidic acid and vaccenic acid in maternal plasma and umbilical blood plasma

\begin{tabular}{|c|c|c|c|c|}
\hline Fatty acid & F-value & Critical probability $P$ & Response & Interpretation \\
\hline Elaidic acid & 100.454 & 0.000 & $\mathrm{H}_{0}$ rejected & Difference in means is statistically significant \\
\hline Vaccenic acid & 111.176 & 0.000 & $\mathrm{H}_{0}$ rejected & Difference in means is statistically significant \\
\hline
\end{tabular}

TABLE 6. The percentage share of maternal plasma samples $(n=53)$ and umbilical blood plasma samples $(n$ $=53$ ) in which elaidic acid or vaccenic acid were not detected

\begin{tabular}{lcc}
\multirow{2}{*}{ Parameters } & \multicolumn{2}{c}{ Percentage share of samples } \\
\cline { 2 - 3 } & elaidic acid & vaccenic acid \\
\hline Maternal plasma & $3.8 \%$ & $3.8 \%$ \\
\hline Umbilical blood plasma & $20.7 \%$ & $66 \%$ \\
\hline
\end{tabular}

TABLE 7. Correlations between the elaidic acid and vaccenic acid levels and the levels of other fatty acids in maternal plasma

\begin{tabular}{|c|c|c|c|c|c|c|c|c|}
\hline Fatty acid & C18:1 t9 & C18:1 t11 & C18:2 n-6 & C18:3 n-6 & C18:3 n-3 & $C 20: 4 n-6$ & $C 20: 5 n-3$ & C22:6n-3 \\
\hline Elaidic acid & nc & 0.85 & 0.43 & nc & 0.42 & nc & nc & 0.42 \\
\hline Vaccenic acid & 0.85 & nc & 0.41 & nc & 0.42 & nc & nc & 0.45 \\
\hline
\end{tabular}

nc - no correlation

TABLE 8. Correlations between the levels of fatty acids in umbilical plasma and the levels of these acids in maternal plasma

\begin{tabular}{|c|c|c|c|c|c|c|c|c|}
\hline \multirow{2}{*}{$\begin{array}{l}\text { Levels of fatty acids in } \\
\text { umbilical plasma }\end{array}$} & \multicolumn{8}{|c|}{ Levels of these acids in maternal plasma } \\
\hline & C18:1 t9 & C18:1 t9 & C18:2 n-6 & C18:3n-6 & C18:3n-3 & C20:4n-6 & C20:5 n-3 & C22:6n-3 \\
\hline C18:1 t9 & nc & $\mathrm{nc}$ & nc & nc & nc & nc & nc & nc \\
\hline C18:1 t9 & nc & -0.35 & nc & nc & nc & nc & nc & nc \\
\hline C18:2 n-6 & nc & $\mathrm{nc}$ & nc & nc & nc & $\mathrm{nc}$ & nc & nc \\
\hline C18:3 n-6 & nc & nc & nc & nc & nc & nc & nc & nc \\
\hline$C 20: 4 n-6$ & nc & $\mathrm{nc}$ & nc & nc & nc & nc & nc & nc \\
\hline$C 20: 5 n-3$ & nc & $\mathrm{nc}$ & nc & nc & $\mathrm{nc}$ & nc & nc & nc \\
\hline$C 22: 6 n-3$ & nc & nc & nc & nc & nc & nc & nc & 0.35 \\
\hline
\end{tabular}

nc - no correlation

fluidity, disturbed reception, and transfer of information by membrane receptors, as well as to altered activity of certain enzymes [21, 25, 33, 35, 36].

In this study, the levels of two TFA isomers: elaidic acid (C18:1 trans-9) and vaccenic acid (C18:1 trans-11) were determined in maternal plasma during the first stage of delivery, as well as in the plasma of blood collected from the umbilical vein. Trans-fatty acids cannot be synthesized in the human body, and thus their presence in the study material is due to the intake of TFA-containing foods by the study mothers during their pregnancy.

Mean maternal plasma levels of both isomers of trans-C18:1 were similar. Due to the metabolic changes that accompany delivery, they were a result of both maternal intake before delivery and release into the blood from adipose tissue, where they had been stored as triglycerides [35, 37]. The delivering mothers had no food for about a dozen or so hours, and were subject to physical and emotional stress due to staying in the 
delivery room and expecting the birth of their offspring. The hormonal consequence of this condition included a relatively low level of insulin and a high level of adrenalin in blood. As a result of these changes, triglycerides in adipocytes undergo lipolysis, releasing free fatty acids and glycerol. The release process is mediated by intracellular triacylglycerol lipase (hormone-sensitive lipase). Free fatty acids are bound by plasma albumin and transported mainly into the liver, muscles and, in the postnatal period, to the mammary gland. Subsequently, they are used as a source of energy or substrates for lipid synthesis [38].

Both the elaidic acid and the vaccenic acid levels in maternal plasma was positively correlated with the levels of linoleic acid (LA), docosahexaenoic acid (DHA) and $\alpha$-linolenic acid (ALA). It may be suspected that the increasing levels of TFAs inhibit the elongation and desaturation of LA and ALA in an increasingly efficient manner, preventing the transformation of LA and ALA into PUFA, and thus increasing their plasma levels. On the other hand, TFAs, as well as LA and ALA, may be of significant importance for the mother and/or the baby during the delivery, as evidenced by their mobilization from the adipose tissue and the increased plasma levels. C18:1 acids, including the trans-isomers, may be an important energy substrate during the delivery, and the elevated concentration of LA, ALA and DHA in maternal blood promotes their transport into the foetal circulation, as confirmed by the positive correlation between ALA levels in maternal plasma and umbilical plasma, as well as the DHA levels in the mother and the newborn.

Elaidic and vaccenic acids was also detected in the plasma of blood collected from the umbilical vein. The umbilical vein facilitates the transportation of oxygen, nutrients and other compounds from the maternal circulation into the foetal circulation. Therefore, the presence of TFAs in umbilical blood is proof of their transfer through the placental barrier. The transfer of TFAs into the foetal circulation had been already observed in earlier studies conducted in animal models, as well as in mothers and newborns [39, 40, 41, 42, 43]. For example, it was demonstrated that labelled elaidic acid administered to pregnant female rats crossed the placental barrier and could be used by foetal tissues as an energy substrate in the $\beta$-oxidation process [36]. Evidence is also available to support the transplacental transfer of TFAs in both animals and humans [36, 39, 40,41,42,43]. Therefore, TFAs may be a factor that increases the risk of developmental defects, not only during intrauterine life, but also in infancy and adult life $[44,45]$. This follows from the theory of the so-called "metabolic programming" that occurs during intrauterine development. Inappropriate nutritional habits of pregnant mothers combined with environmental factors may disturb the foetal metabolism, predisposing the baby to cardiovascular or metabolic diseases (hypertension, obesity, diabetes) in adult life $[46,47]$.

The mean levels of the analyzed trans-isomers of C18:1 in the umbilical vein were 7 to 14 times lower than in the plasma of the delivering mothers (the difference was statistically significant), which might suggest the impact of factors restricting their transport through the placenta, or their metabolism within the placenta tissue, i.e. before entering the foetal circulation.

Of note is the fact that despite both acids being present in the plasma of $96.2 \%$ of women in the first stage of delivery, C18:1 trans-9 was present in umbilical plasma at detectable levels in $79.2 \%$ of samples, while C18:1 trans-11 was present at detectable levels in only $44 \%$ of samples. Such results could be due to the time interval between the collection of blood from the mother and the neonate, lasting up to several hours, or even a dozen or so hours. This hypothesis may also be confirmed by the demonstration of a negative correlation between the levels of vaccenic acid in maternal plasma and umbilical plasma. The observed effect may also be due to the presence of mechanisms that restrict the placental transfer of this acid when its maternal circulation level is increased. The metabolism of vaccenic acid into rumenic acid (RA, C18:2 cis-9, trans-11) mediated $\Delta^{9}$-desaturase should also be taken into account. Earlier, Turpeinen et al. observed that the increase in the levels of rumenic acid in blood serum was positively correlated with the increase in vaccenic acid levels [48]. The increase in the levels of C18:1 trans-11 in maternal plasma could trigger its transformation into RA, thus reducing its transport through the placenta into the foetal circulation. However, the RA levels were not determined in the study material, making the hypothesis impossible to verify.

A positive correlation was recently observed between the elaidic acid levels and the vaccenic acid levels in umbilical plasma. This suggests that the placental transport and/or metabolism of these compounds are somehow related to each other. Perhaps both isomers are incorporated into the same triacylglycerol molecules, and thus enter the foetal circulation. It is also possible that both elaidic and vaccenic acid enter the foetal circulation in the form of free acids. Taking into account earlier reports by other authors, it might be suspected that elaidic acid and vaccenic acid were used as structural, energy and reserve substrates in the systems of the mothers and neonates included in the studies [21, 25, 33, 35].

It is suspected that trans-isomers of oleinic acid (C18:1), generated in the process of the hydrogenation of unsaturated fatty acids originating from vegetable oils, have an adverse effect on the growth and development of the system, as they inhibit the transformation of linoleic acid (C18:2 n-6) into arachidonic acid (C20:4 n-6) and the transformation of $\alpha$-linolenic acid (C18:3 n-3) into docosahexaenoic acid (C22:6 n-3) [18, 19, 20, 21, 22, 23]. These long-chain polyunsaturated fatty acids (LC-PUFAs) affect, among others, the development of the nervous system [49]. Several studies conducted in vitro or in animal models confirmed the hypothesis that TFAs might disturb the formation of double bonds within the linoleic acid hydrocarbon chains [50]. It is also possible that a TFA-rich diet is also low in n-6 and n-3 acids, thus limiting their supply [51].

Earlier studies revealed a statistically significant negative correlation between the levels of TFA and LC-PUFA in, e.g.: umbilical blood in healthy in-term neonates $[41,52]$ and in-term neonates with atopy features [52], within the lipid structures of umbilical vessel walls in healthy in-term neonates [53], in 
plasma lipoprotein fractions in pre-term neonates [39, 41, 52], as well as in plasma lipoprotein fractions in children aged 1 to 15 years [54].

A negative correlation was observed between the levels of trans isomers of C18:1 and C18:2tt and the levels of n-3 and n-6 PUFAs [37, 41]. In 308 healthy, in-term newborns the increase in TFA C18:1 levels in the lipid structures of the umbilical vessel walls reduced the levels of DHA [53]. A similar trend was observed by Elias and Innis [41], who analyzed the content of TFA, LA, arachidonic acid (AA) and DHA in the triglycerides and cholesteryl ester fraction of umbilical blood plasma.

By restricting the synthesis of LC-PUFAs, TFAs adversely affect foetal growth and development and, in consequence, the neonatal birth weight $[22,39,41,55,56]$. In addition, proper development of the nervous system, during both foetal and postnatal periods, is determined by LC-PUFAs [54, 57]. However, it appears that the TFA levels must be relatively high (to a degree unprecedented in the average human diet) in order to disturb LA desaturation [58]. As demonstrated by Koletzko, there is a negative relationship between the levels of elaidic acid in neonatal plasma and birth weight, but there is no relationship between these levels and the duration of pregnancy [39]. Dirix et al. found that body weight was negatively correlated with the levels of trans-isomers in umbilical blood erythrocytes [59]. On the other hand, Elias and Innis demonstrated that the levels of TFA in neonatal plasma were negatively correlated with the duration of pregnancy but had no effect on the birth weight and the body length of neonates [41].

In contrast to previous studies, no effect of TFAs on birth weight or neonatal body length were observed.

Exposure to TFAs present in natural conditions in the fat of ruminant animals may pose the same risk of cardiovascular diseases as in the case of TFAs obtained in industrial processes [60], although some reports suggest no effect, or even a positive effect of these acids on the blood levels of individual lipid fractions $[61,62,63]$. Due to numerous reports on the negative effects of TFA, women should pay attention to the food they consume as early as in the pre-conception period, and most definitely during the pregnancy, as the half-life of fatty acids within the adipocytes is ca. 680 days [64].

\section{CONCLUSIONS}

The presence of trans-unsaturated fatty acids (elaidic acid and vaccenic acid) in umbilical plasma is evidence of the transplacental transport of these acids. The significantly higher levels of elaidic acid compared to vaccenic acid in umbilical plasma, with comparable levels of both acids in maternal plasma, suggests that vaccenic acid is more extensively metabolized in the placenta. The levels of trans-unsaturated fatty acids in maternal plasma and umbilical plasma as determined in this study had no effect on the birth weight and the body length of neonates.

\section{REFERENCES}

1. Aro A., Kardinaal A.F.M., Salminen I., Kark J.D., Riemersma R.A., Delgado-Rodriguez M. et al.: Adipose tissue isomeric trans fatty acids and risk of myocardial infarction in nine countries: the EURAMIC study. Lancet. 1995, 345 (8945), 273-278.

2. Hu F.B., Stampfer M.J., Manson J.E., Rimm E., Colditz G.A., Rosner B.A. et al.: Dietary fat intake and the risk of coronary heart disease in women. $\mathrm{N}$ Engl J Med. 1997, 337 (21), 1491-1499.

3. Mensink R.P., Zock P.L., Kester A.D., Katan M.B.: Effects of dietary fatty acids and carbohydrates on the ratio of serum total HDL cholesterol and on serum lipids and apolipoproteins: a meta-analysis of 60 controlled trials. Am J Clin Nutr. 2003, 77 (5), 1146-1155.

4. Roberts T.L., Wood D.A., Riemersma R.A., Gallagher P.J., Lampe F.C.: Trans isomers of oleic and linoleic acids in adipose tissue and sudden cardiac death. Lancet. 1995, 345 (8945), 278-282.

5. Judd, J.T., Clevidence B.A., Muesing R.A., Wittes J., Sunkin M.E., Podczasy J.J.: Dietary trans fatty acids: effects on plasma lipids and lipoproteins of healthy men and women. Am J Clin Nutr. 1994, 59 (4), 861-868.

6. Katan M.B., Zock P.L., Mensink R.P.: Trans fatty acids and their effects on lipoproteins in humans. Annu Rev Nutr. 1995, 15, 473-493.

7. Kuhnt K., Wagner A., Kraft J., Basu S., Jahreis G.: Dietary supplementation with 11 trans- and 12 trans 18:1 and oxidative stress in humans. Am J Clin Nutr. 2006, 84 (5), 981-988.

8. Troisi R., Willett W.C., Weiss S.T.: Trans-fatty acid intake in relation to serum lipid concentrations in adult men. Am J Clin Nutr. 1992, 56 (6), 1019-1024.

9. Lopez-Garcia E., Schulze M.B., Meigs J.B., Manson J.E., Rifai N., Stampfer M.J. et al.: Consumption of trans fatty acids is related to plasma biomarkers of inflammation and endothelial dysfunction. J Nutr. 2005, 135 (3), 562-566.

10. Mozaffarian D., Pischon T., Hankinson S.E., Rifai N., Joshipura K., Willett W.C. et al:: Dietary intake of trans fatty acids and systemic inflammation in women. Am J Clin Nutr. 2004, 79 (4), 606-612.

11. Mozaffarian D., Rimm E.B., King I.B., Lawler R.L., McDonald G.B., Levy W.C.: Trans fatty acids and systemic inflammation in heart failure. Am J Clin Nutr. 2004, 80 (6), 1521-1525.

12. Ibrahim A., Natrajan S., Ghafoorunissa R.: Dietary trans-fatty acids alter adipocyte plasma membrane fatty acid composition and insulin sensitivity in rats. Metabolism. 2005, 54 (2), 240-246.

13. Salmeron J., Hu F.B., Manson J.E., Stampfer M.J., Colditz G.A., Rimm E.B. et al.: Dietary fat intake and risk of type 2 diabetes in women. Am J Clin Nutr. 2001, 73 (6), 1019-1026.

14. King I.B., Kristal A.R., Schaffer S., Thornquist M., Goodman G.E.: Serum trans-fatty acids are associated with risk of prostate cancer in beta-carotene and retinol efficacy trial. Cancer Epidemiol Biomarkers Prev. 2005, 14 (4), 988-992.

15. Kohlmeier L., Simonsen N., van't Veer P., Strain J.J., Martin-Moreno J.M., Margolin B. et al.: Adipose tissue trans fatty acids and breast cancer in the European community multicenter study on antioxidants, myocardial infarction and breast cancer. Cancer Epidemiol Biomarkers Prev. 1997, 6 (9), 705-710.

16. Liu X., Schumacher F.R., Plummer S.J., Jorgenson E., Casey G., Witte J.S.: Trans-fatty acid intake and increased risk of advanced prostate cancer: modification by RNASEL R462Q variant. Carcinogenesis. 2007, 28 (6), 1232-1236.

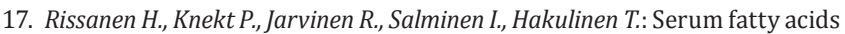
and breast cancer incidence. Nutr Cancer. 2003, 45 (2), 168-175.

18. Cook H.W., Emken E.A.: Geometric and positional fatty acid isomers interact differently with desaturation and elongation of linoleic and linolenic acids in cultured glioma cells. Biochem Cell Biol. 1990, 68 (3), 653-660.

19. De Schrijver R., Privett O.S.: Interrelationship between dietary trans fatty acids and the 6- and 9-desaturases in the rat. Lipids. 1982, 17 (1), 27-34.

20. Kurata N., Privett O.S.: Effects of dietary trans acids on the biosynthesis of arachidonic acid in rat liver microsomes. Lipids. 1980, 15 (12), 1029-1036.

21. Larque E., Garcia-Ruiz P.A., Perez-Llamas F., Zamora S., Gil A.: Dietary trans fatty acids alter the compositions of microsomes and mitochondria and the activities of microsome delta6-fatty acids desaturase and glucose-6-phosphatase in livers of pregnant rats. J Nutr. 2003, 133 (8), 2526-2531.

22. Larque E., Perez-Llamas F., Puerta V., Giron M.D., Suarez M.D., Zamora S. et al.: Dietary trans fatty acids affect docosahexaenoic acid concentra- 
tions in plasma and liver but not brain of pregnant and fetal rats. Pediatr Res. 2000, 47 (2), 278-283.

23. Rosenthal M.D., Doloresco M.A.: The effects of trans fatty acids on fatty acyl delta 5 desaturation by human skin fibroblasts. Lipids. 1984, 19 (11), 869-874.

24. Stachowska E., Dołęgowska B., Chlubek D., Wesołowska T., Ciechanowski K., Gutowski P. et al.: Dietary trans fatty acids composition of human atheromatous plaques. Eur J Nutr. 2004, 43 (5), 313-318.

25. Holman R.T., Pusch F., Svingen B., Dutton H.J.: Unusual isomeric polyunsaturated fatty acids in liver phospholipids of rats fed hydrogenated oil. Proc Natl Acad Sci USA. 1991, 88 (11), 4830-4834.

26. Hunter J.E.: Dietary trans fatty acids: review of recent human studies and food industry responses. Lipids. 2006, 41 (11), 967-992.

27. Martin C.A., Milinsk M.C., Visentainer J.V., Matsushita M., de-Souza N.E.: Trans fatty acid-forming processes in foods: a review. An Acad Bras Cienc. 2007, 79 (2), 343-350.

28. Mosley E.E., Powell G.L., Riley M.B., Jenkins T.C.: Microbial biohydrogenation of oleic acid to trans isomers in vitro. J Lipid Res. 2002, 43 (3), 290-296.

29. Botham K.M., Mayes P.A.: Lipidy o znaczeniu fizjologicznym. In: Biochemia Harpera. Eds. R.K. Murray. PZWL, Warszawa 2008, 149-161.

30. Aro A., Amaral E., Kesteloot H., Rimestad A., Thamm van Poppel G.: Trans fatty acids in french fries, soups, and snacks from 14 European countries: The TRANSFAIR study. J Food Comp Anal. 1998, 11 (2), 170-177.

31. Innis S.M., Green T.J., Halsey T.K.: Variability in the trans fatty acid content of foods within a food category: implications for estimation of dietary trans fatty acids intakes. J Am Coll Nutr. 1999, 18 (3), 255-260.

32. Gebauer S.K., Psota T.L., Kris-Etherton P.M.: The diversity of health effects of individual trans fatty acids isomers. Lipids. 2007, 42 (9), 787-799.

33. Kraft J., Hanske L., Mockel P., Zimmermann S., Hartl A., Kramer J.K. et al.: The conversion efficiency of trans-11 and trans-12 18:1 by delta 9 desaturation differs in rats. J Nutr. 2006, 136 (9), 1209-1214.

34. Wolff R.L., Precht D.: Reassessment of the contribution of bovine milk fats to the trans-18:1 isomeric acid consumption by European populations. Additional data for rumenic (cis-9, trans-11 18:2) acid. Lipids. 2002, 37 (12), 1149-1150.

35. McCloy U., Ryan M.A., Pencharz P.B., Ross R.J., Cunnane S.C.: A comparison of the metabolism of eighteen-carbon $13 \mathrm{C}$-unsaturated fatty acids in healthy women. J Lipid Res. 2004, 45 (3), 474-485.

36. Moore C.E., Dhopeshwarkar G.A.: Placental transport of trans fatty acids in the rat. Lipids. 1980, 15 (12), 1023-1028.

37. Szabo E., Boehm G., Beermann C., Weyermann M., Brenner H., Rothenbacher D. et al.: Trans octadecenoic acid and trans octadecadienoic acid are inversely related to long-chain polyunsaturates in human milk: results of a large birth cohort study. Am J Clin Nutr. 2007, 85 (5) 1320-1326.

38. Rudolph M.C., Neville M.C., Anderson S.M.: Lipid synthesis in lactation: diet and the fatty acid switch. J Mammary Gland Neoplasia. 2007, 12 (4), 269-281.

39. Koletzko B.: Trans fatty acids may impair biosynthesis of long chain polyunsaturates and growth in man. Acta Paediatr. 1992, 81 (4), 302-306.

40. Berghaus T.M., Demmelmair H., Koletzko B.: Fatty acid composition of lipid classes in maternal and cord plasma at birth. Eur J Pediatr. 1998, 157 (9), 763-768.

41. Elias S.L., Innis S.M.: Infant plasma trans, n-6, and n-3 fatty acids and conjugated linoleic acids are related to maternal plasma fatty acids, length of gestation, and birth weight and length. Am J Clin Nutr. 2001, 73 (4), 807-814.

42. Jakobik V., Burus I., Decsi T:: Fatty acids composition of erythrocyte membrane lipids in health subjects from birth to young adulthood. Eur J Pediatr. 2009, 168 (2), 141-147.

43. Koletzko B., Muller J.: Cis- and trans-isomeric fatty acids in plasma lipids of newborn infants and their mothers. Biol Neonate. 1990, 57 (3-4), 172-178.

44. Albuquerque K.T., Sardinha F.L., Telles M.M., Watanabe R.L., Nascimento C.M., Tavares do Carmo M.G. et al.: Intake of trans fatty acid-rich hydrogenated fat during pregnancy and lactation inhibits the hypophagic effect of central insulin in the adult offspring. Nutrition. 2006, 22 (7-8), 820-829.

45. Herrera E.: Implications of dietary fatty acids during pregnancy on placental, fetal and postnatal development - a review. Placenta. 2002, 23 (Suppl. A), S9-S19.

46. Barker D.J.: In utero programming of chronic disease. Clin Sci (Lond). 1998, 95 (2), 115-128.

47. Godfrey K.M., Barker D.J.: Fetal programming and adult health. Public Health Nutr. 2001, 4 (2), 611-624.

48. Turpeinen A.M., Mutanen M., Aro A., Salminen I., Basu S., Palmquist D.L. et al.: Bioconversion of vaccenic acid to conjugated linoleic acid in humans. Am J Clin Nutr. 2002, 76 (3), 504-510.

49. Koletzko B., Mrotzek M., Bremer H.J.: Fatty acids composition of mature human milk in Germany. Am J Clin Nutr. 1988, 47 (6), 954-959.

50. Del Prado M., Villalpando S., Elizondo A., Rodriguez M., Demmelmair H., Koletzko B.: Contribution of dietary and newly formed arachidonic acid to human milk lipids in women eating a low-fat diet. Am J Clin Nutr. 2001, 74 (2), 242-247.

51. Innis S.M., King D.J.: Trans fatty acids in human milk are inversely associated with concentrations of essential all-cis n- 6 and n-3 fatty acids and determine trans, but not n- 6 and n-3 fatty acids in plasma lipids of breast-fed infants. Am J Clin Nutr. 1999, 70 (3), 383-390.

52. Decsi T., Burus I., Molnar S., Minda H., Veitl V.: Inverse association between trans isomeric and long-chain polyunsaturated fatty acids in cord blood lipids of full term-infants. Am J Clin Nutr. 2001, 74 (3), 364-368.

53. Decsi T., Boehm G., Tjoonk H.M., Molnar S., Dijck-Brouwer D.A., Hadders-Algra M. et al.: Trans isomeric octadecenoic acids are related inversely to arachidonic acid and DHA and positively related to mead acid in umbilical vessel wall lipids. Lipids. 2002, 37 (10), 959-965.

54. Decsi T., Koletzko B.: Role of long-chain polyunsaturated fatty acids in early human neurodevelopment. Nutr Neurosci. 2000, 3, 293-306.

55. Carlson S.E., Clandinin M.T., Cook H.W., Emken E.A., Filer J.L. Jr.: Trans Fatty acids: infant and fetal development. Am J Clin Nutr. 1997, 66 (3), 715S-736S.

56. von Houwelingen A.C., Hornstra G.: Trans fatty acids in early human development. World Rev Nutr Diet. 1994, 75, 175-178.

57. Bouwstra H., Dijck-Brouwer J., Decsi T., Boehm G., Boersma E.R., Muskiet F.A. et al: Neurologic condition of healthy term infants at 18 months: positive association with venous umbilical DHA status and negative association with umbilical trans-fatty acids. Pediatr Res. 2006, 60 (3), 334-339.

58. Zevenbergen J.L., Houtsmuller U.M., Gottenbos J.J.: Linoleic acid requirement of rats fed trans fatty acids. Lipids. 1988, 23 (3), 178-186.

59. Dirix C.E., Kester A.D., Hornstra G.: Associations between term birth dimensions and prenatal exposure to essential and trans fatty acids. Early Hum Dev. 2009, 85 (8), 525-530.

60. Rice B.H., Kraft J., Destaillats F., Bauman D.E., Lock A.L.: Ruminant-produced trans-fatty acids raise plasma total and small HDL particle concentrations in male hartley guinea pigs. J Nutr. 2010, 140 (12), 2173-2179.

61. Chardigny J.M., Destaillats F., Malpuech-Brugere C., Moulin J., Bauman D.E., Lock A.L. et al:: Do trans fatty acids from industrially produced sources and from natural sources have the same effect on cardiovascular disease risk factors in healthy subjects? Results of the trans Fatty Acids Collaboration (TRANSFACT) study. Am J Clin Nutr. 2008, 87 (3), 558-566.

62. Motard-Belanger A., Charest A., Grenier G., Paquin P., Chouinard Y., Lemieux S. et al.: Study of the effect of trans fatty acids from ruminants on blood lipids and other risk factors for cardiovascular disease. Am J Clin Nutr. 2008, 87 (3), 593-599.

63. Tholstrup T., Raff M., Basu S., Nonboe P., Sejrsen K., Straarup E.M.: Effects of butter high in ruminant trans and monounsaturated fatty acids on lipoproteins, incorporation of fatty acids into lipid classes, plasma C-reactive protein, oxidative stress, hemostatic variables, and insulin in healthy young men. Am J Clin Nutr. 2006, 83 (2), 237-243.

64. Sun Q., Ma J., Campos H., Hankinson S.E., Hu F.B.: Comparison between plasma and erythrocyte fatty acid content as biomarkers of fatty acid intake in US women. Am J Clin Nutr. 2007, 86 (1), 74-81. 